\title{
NON-INVASIVE DIAGNOSIS OF GASTROESOPHAGEAL REFLUX DISEASE USING GASTRIN- AND PEPSINOGEN-BASED TESTS
}

\author{
Georgijs Moisejevs ${ }^{1,2,3, \#}$, Ilva Daugule ${ }^{1}$, Sergejs Isajevs ${ }^{1,4}$, Dace Rudzìte ${ }^{1,5}$, \\ Dainius Janciauskas ${ }^{1,6}$, Ivars Tolmanis ${ }^{7,8}$, and Marcis Leja ${ }^{1,7,9}$ \\ ${ }^{1}$ Faculty of Medicine, University of Latvia, 6 Linezera Str., LV1006, Rīga, Latvia \\ ${ }^{2}$ Scientific Laboratory of Molecular Genetics, Rīga Stradiṇš University, Rīga, Latvia \\ ${ }^{3}$ Department of Nephrology and Renal Replacement Therapies, Rīga East University Hospital, Rĩga, Latvia \\ ${ }^{4}$ Department of Pathology, Rīga East University Hospital, Rīga, Latvia; \\ ${ }^{5}$ Laboratory of Microbiology, Rīga East University Hospital, Rīga, Latvia; \\ ${ }^{6}$ Faculty of Medicine, Lithuanian University of Health Sciences, Kaunas, Lithuania; \\ ${ }^{7}$ Centre of Digestive Diseases "GASTRO", Rīga, Latvia; \\ ${ }^{8}$ Department of Internal Medicine, Rīga Stradiṇš University, Rīga, Latvia \\ ${ }^{9}$ Department of Science, Rīga East University Hospital, Rīga, Latvia \\ \# Corresponding author, georgijs.moisejevs@gmail.com
}

Contributed by Mārcis Leja

\begin{abstract}
Gastrin-17 (G-17), pepsinogen-1 (Pg1) and pepsinogen-2 (Pg2) reflect the functional state of gastric mucosa and are used for non-invasive diagnosis and screening of atrophic gastritis. The aim of the study was to clarify if erosive reflux disease (ERD) or non-ERD (NERD) can be distinguished from other dyspeptic conditions in patients, in a non-invasive manner using specific biomarkers. Levels of G-17, Pg1, and Pg2 were measured in 141 ERD patients (median age 48 years, males - 68), 122 NERD patients (median age 45 years, males - 32) and 410 control patients (median age 50 years, males - 97). Levels of biomarkers in ERD and NERD groups were compared to controls. Median levels of G-17 (1.94 vs $2.92 \mathrm{pmol} / \mathrm{L}, p=0.036)$ and Pg2 (6.70 vs $7.79 \mu \mathrm{g} / \mathrm{l}, \mathrm{p}=0.046)$ were lower in the ERD group compared to control patients; no difference with respect to the control was found for the NERD group. After exclusion of the patients having at least one potential condition that might modify the levels of the biomarkers (gastric mucosa atrophy, Helicobacter pylori colonisation), no difference in levels of biomarkers was observed with respect to the control for both the ERD and NERD groups. G-17, Pg1, and Pg2 based tests cannot be used to distinguish ERD or NERD from other dyspeptic conditions in patients.
\end{abstract}

Key words: gastroesophageal reflux disease, gastrin-17, pepsinogen-1, pepsinogen-2.

\section{INTRODUCTION}

Gastroesophageal reflux disease (GERD) is characterised by abnormal excessive acidic gastric content reflux in esophagus and it has complex pathophysiology (Mulholland et al., 1989; Collen and Johnson, 1992; Abe et al., 2009). Production of gastric acid is controlled by various physiological mechanisms, involving gastrin-17 (G-17) exclusively produced by the $\mathrm{G}$ cells located in the antral mucosa of stomach (Gritti et al., 2000; Dockray, 2004). G-17 is crucial acid secretion stimulator, controlled via negative feedback mechanisms.
Pepsinogen-1 (Pg1), a precursor of pepsin, is produced by the chief and mucus cells located in the corpus mucosa of the stomach. Pepsinogen-2 (Pg2) is produced not only in the corpus mucosa, but also in antral and duodenal mucosa (Gritti et al., 2000). Some studies have demonstrated different gastric acid exposure profiles among various forms of erosive reflux disease (Mulholland et al., 1989; Collen and Johnson, 1992). Since the levels of these biomarkers reflect functional state of the gastric mucosa, they are used for non-invasive diagnosis and screening for atrophic gastritis (Kuipers, 2003; Vaananen et al., 2003; Pasechnikov et al., 2005; Iijima et al., 2009; Narsollahzadeh et al., 2011). For 
example, an increased level of G-17 may reflect atrophy of corpus mucosa or inflammation of antral mucosa, while a decreased G-17 level suggests atrophy of the antral mucosa. All of these biomarkers are involved in the secretion and production of the gastric acid, but it still remains unclear if there is any association among levels of biomarkers and gastroesophageal reflux disease.

The aim of the study was to clarify if Erosive reflux disease (ERD) or non-ERD (NERD) could be distinguished from other dyspeptic conditions in patients, in a non-invasive manner using G-17, Pg1, and Pg2 based tests.

\section{MATERIALS AND METHODS}

Study design. Patients with various complaints concerning the side of upper gastrointestinal system, who visited the outpatient department of Rìga East Clinical University Hospital (Rīga, Latvia) and Centre of Digestive Diseases "GASTRO” (Rịga, Latvia) during the time period 2005-2011, were invited to participate in the study. In total 841 dyspeptic patients were interviewed and asked to fill in a special questionnaire about their complaints (heartburn, acid regurgitation, loss of appetite, postprandial fullness, early satiation, epigastric pain, vomitus and other), medical history (cancer anamnesis, previous operations etc.) and history of drug usage (proton pump inhibitors, Helicobacter pylori eradication therapy and histamine-2 antagonists).

In the questionnaire about patient complaints, the patients answered "yes" or "no" to all questions except those about heartburn and acid regurgitation (Table 1). Dyspepsia was defined in accordance to the Rome III criteria as the presence of at least one of four cardinal dyspepsia symptoms (postprandial fullness, early satiation, epigastric pain or epigastric burning), in the absence of organic or metabolic disturbances likely to explain those symptoms (Tack et al., 2006). After the interview a blood sample was taken from each patient and then upper gastrointestinal endoscopy with standard biopsy was performed.

The following inclusion criteria were used: dyspeptic patients identified as Rome III criteria, age at least 18 years, non-pregnant, willing to participate in the study and did not meet exclusion criteria.

The following exclusion criteria were used: use of proton pump inhibitors and/or histamine-2 antagonists during the last month, active ulcer disease, gastric cancer, gastric lym-

Table 1

PATIENT COMPLAINTS

\begin{tabular}{l|cc}
\hline \multirow{2}{*}{} & \multicolumn{2}{|c}{ Number of patients $(\mathrm{n}=673)$} \\
\cline { 2 - 3 } & Heartburn & Acid regurgitation \\
\hline All the time & 99 & 45 \\
Every day & 45 & 19 \\
Twice a week & 9 & 2 \\
Sometimes & 6 & 1 \\
Never & 514 & 606
\end{tabular}

phoma, Barrett's esophagus (BE), hiatus hernia of esophagus and history of any type of gastric surgery.

According to the medical history and endoscopic finding, the patients $(n=673)$ were divided into three groups (Katz et al., 2013): the ERD group consisted of patients with visible esophageal mucosa breaks (ulcers and/or erosions) elevated according to the Los Angeles classification (Lundell et al., 1999), NERD patients were defined as having symptoms with known quality and duration (heartburn and/or acid regurgitation appearing at least twice a week for at least six months) and having no visible esophageal mucosa breaks (Dixon et al., 1996), and a control group was composed of other patients with various complaints about the upper gastrointestinal system's side and having no evidence of any form of gastroesophageal reflux disease.

Levels of detected biomarkers and their ratios in the ERD and NERD study groups were compared to control patients. To clarify if changes in the levels of the biomarkers were influenced by underlying changes of gastric mucosa, the levels of the biomarkers and their ratios were compared among patient groups after exclusion of all patients having at least one potential condition that might modify the levels of the biomarkers (gastric corpus and antrum mucosa atrophy, Helicobacter pylori colonisation of gastric mucosa).

Plasma biomarkers. A blood sample from each patient was taken after night fasting prior to upper gastrointestinal endoscopy or 24 hours after the procedure. Blood plasma was separated from the whole blood, frozen immediately and stored at $-80{ }^{\circ} \mathrm{C}$ in the laboratory. Then, levels of $\mathrm{Pg} 1, \mathrm{Pg} 2$ and G-17 was measured by specific enzyme linked immunosorbent assay (Pepsinogen-I EIA Test kit, Pepsinogen-II EIA Test kit and Gastrin-17 EIA Test kit, GastroPanel ${ }^{\circledR}$, Biohit Oyj., Helsinki, Finland) according to the manufacture's instructions. In addition the $\mathrm{Pg} 1$ and $\mathrm{Pg} 2$ ratio (Pg1/Pg2) was calculated.

Upper gastrointestinal tract endoscopy. Upper gastrointestinal tract endoscopy was done after night fasting. Presence of esophageal mucosa breaks (ulcers and/or erosions) was evaluated according to Los Angeles classification (Lundell et al., 1999). Standard biopsy material from each patient was taken during the procedure from at least five different loci of the stomach in accordance to the updated Sydney system: two from corpus mucosa (one from the lesser and one from the greater curvature), one from incisura angularis mucosa (from the lesser curvature) and two from antrum mucosa (one from the lesser and one from the greater curvature) (Dixon et al., 1996). Additional biopsies were taken from any columnar-lined mucosa of the lower part of esophagus.

Histopathology. An experienced expert gastrointestinal histopathologist (DJ), blinded from any clinical data, examined all of the biopsies. All findings were reported separately for each site of stomach: corpus, incisura angularis and antrum. Staining with haematoxylin and eosin was done for evaluation of gastric mucosa atrophy. Giemsa staining 
LEVELS OF BIOMARKERS IN THE STUDY GROUPS

\begin{tabular}{|c|c|c|c|c|c|}
\hline & $\begin{array}{c}\text { ERD } \\
\mathrm{n}=141 \\
\text { median (IQR) }\end{array}$ & $\begin{array}{c}p \\
\text { ERD versus Control }\end{array}$ & $\begin{array}{c}\text { NERD } \\
\mathrm{n}=122 \\
\text { median (IQR) }\end{array}$ & $\begin{array}{c}p \\
\text { NERD versus Control }\end{array}$ & $\begin{array}{c}\text { Control } \\
\mathrm{n}=410 \\
\text { median (IQR) }\end{array}$ \\
\hline G-17 (pmol/1) & $1.94(0.54-5.72)$ & 0.036 & $3.18(0.80-9.53)$ & 0.532 & $2.92(0.57-10.11)$ \\
\hline $\operatorname{Pg} 1(\mu \mathrm{g} / \mathrm{l})$ & $63.10(50.91-92.04)$ & 0.434 & $71.10(51.26-96.55)$ & 0.058 & $64.03(44.05-89.85)$ \\
\hline $\operatorname{Pg} 2(\mu \mathrm{g} / \mathrm{l})$ & $6.70(4.84-10.80)$ & 0.046 & $8.63(5.05-12.82)$ & 0.609 & $7.79(5.24-13.03)$ \\
\hline $\operatorname{Pg} 1 / \operatorname{Pg} 2$ & $9.41(7.02-11.95)$ & 0.008 & $8.60(6.40-11.82)$ & 0.377 & $8.60(5.23-11.30)$ \\
\hline
\end{tabular}

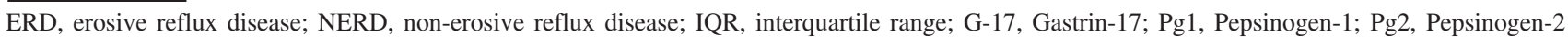

was used to determine density of Helicobacter pylori gastric mucosa colonisation.

The loss of appropriate glands with or without metaplastic epithelial transformation was defined as mucosa atrophy and was scored using visual analogue scales $(0=$ absent, $1=$ mild, 2 = moderate, 3 = severe) (Dixon et al., 1996).

Biopsies from the incisura angularis and antrum mucosa were considered as the antral mucosa. The highest score for estimated parameters was used in the analysis.

The diagnosis of Barrett's esophagus was made if the specialised metaplastic columnar epithelium with goblet and/or pre-goblet cells was confirmed by histopathological examination in biopsy samples taken from any columnar-lined mucosa of the lower part of esophagus.

Statistical analysis. Distribution of age was characterised using median and range. Frequency of gender is shown in per cents. Distribution of biomarkers and their ratio was characterised by median and interquartile range (IQR = $\mathrm{Q}_{1}-\mathrm{Q}_{3}$ ). Bivariate comparison of medians of biomarker levels and their ratios between groups was done using the Mann-Whitney U test. Statistically significant difference was considered if the $p$-value was below 0.05. All analyses were generated using SPSS 20.0 (SPSS Inc., Chicago, IL, USA).

Ethical consideration. The local Committee of Ethics approved study protocol before patient recruitment was started. All patients signed an informed consent form prior the admission.

\section{RESULTS}

The final sample included 673 patients: 141 patients in the ERD group (median age 48 years (range 18-84), male/female ratio $(\mathrm{M} / \mathrm{F})$ - 68/83); 122 patients in the NERD group (median age 45 years (range 18-78), M/F - 32/90) and 410 patients in the control group (median age 50 years (range 18-90), M/F - 97/313).

The distribution of ERD severity according to the Los Angeles classification (Lundell et al., 1999) was as follows: grade A - 108/141 (76.6\%), grade B - 25/141 (17.7\%), grade $\mathrm{C}-6 / 141(4.3 \%)$, and grade $\mathrm{D}-2 / 141(1.4 \%)$.
Median level of G-17 was significantly lower in the ERD group compared to control patients (respectively, 1.94 $\mathrm{pmol} / \mathrm{l}$ versus $2.92 \mathrm{pmol} / \mathrm{l}, p=0.036$ ). Levels of all other biomarkers and their ratio, with the exception of Pg1, significantly differed between ERD group and control patients. However, levels of biomarkers and their ratio did not significantly differ between NERD and control group patients. The bivariate comparison of levels of biomarkers and their ratio is shown in the Table 2.

Patients who after histopathological evaluation showed potential conditions that might modify levels of biomarkers were excluded from the study groups: 81 patients from the ERD group; 85 from the NERD group and 282 from the control group (Table 3).

The numbers of remaining patients were 60 in the ERD group, 37 in the NERD group and 128 in the control group. After exclusion of the above patients, median level of G-17 in the ERD group showed no difference compared to control patients (respectively, $0.81 \mathrm{pmol} / 1$ versus $0.74 \mathrm{pmol} / \mathrm{l}$, $p=0.956$ ). Levels of all other biomarkers and their ratios were not significantly different in ERD and NERD groups compared to control patients. The bivariate comparison of levels of biomarkers after exclusion of all potential conditions that might modify levels of biomarkers is shown in Table 4.

\section{DISCUSSION}

Our study was focused on the evaluation of a possible alternative diagnostic method to distinguish GERD from other

$$
\text { Table } 3
$$

NUMBER OF IDENTIFIED POTENTIAL CONDITIONS THAT MIGHT MODIFY LEVELS OF BIOMARKERS

\begin{tabular}{l|c|c|c}
\hline \multirow{2}{*}{} & \multicolumn{3}{|c}{ Number of patients } \\
\cline { 2 - 4 } & $\begin{array}{c}\text { ERD } \\
\mathrm{n}=141\end{array}$ & $\begin{array}{c}\text { NERD } \\
\mathrm{n}=122\end{array}$ & $\begin{array}{c}\text { Controls } \\
\mathrm{n}=410\end{array}$ \\
\hline $\begin{array}{l}\text { Antrum mucosa atrophy (any grade) } \\
\text { Corpus mucosa atrophy (any grade) }\end{array}$ & 29 & 38 & 104 \\
$\begin{array}{l}\text { Helicobacter pylori colonization of } \\
\text { antrum mucosa }\end{array}$ & 63 & 10 & 65 \\
$\begin{array}{l}\text { At least one from the above mentioned } \\
\text { factors present }\end{array}$ & 81 & 67 & 215 \\
\end{tabular}

ERD, erosive reflux disease; NERD, non-erosive reflux disease 
LEVELS OF BIOMARKERS IN THE STUDY GROUPS AFTER EXCLUSION OF ALL POTENTIAL CONDITIONS THAT MIGHT MODIFY LEVELS OF BIOMARKERS

\begin{tabular}{|c|c|c|c|c|c|}
\hline & $\begin{array}{c}\text { ERD } \\
\mathrm{n}=60 \\
\text { median }(\mathrm{IQR})\end{array}$ & $\begin{array}{c}p \\
\text { ERD versus Control }\end{array}$ & $\begin{array}{c}\text { NERD } \\
\mathrm{n}=37 \\
\text { median (IQR) }\end{array}$ & $p$ NERD versus Control & $\begin{array}{c}\text { Control } \\
\mathrm{n}=128 \\
\text { median (IQR) }\end{array}$ \\
\hline $\mathrm{G}-17(\mathrm{pmol} / \mathrm{l})$ & $0.81(0.25-3.79)$ & 0.956 & $1.06(0.30-5.97)$ & 0.243 & $0.74(0.05-3.25)$ \\
\hline $\operatorname{Pg} 1(\mu \mathrm{g} / \mathrm{l})$ & $60.71(50.79-72.77)$ & 0.607 & $64.63(47.33-88.35)$ & 0.389 & $59.62(44.97-79.77)$ \\
\hline $\operatorname{Pg} 2(\mu \mathrm{g} / \mathrm{l})$ & $5.37(4.54-7.37)$ & 0.895 & $5.08(4.11-10.49)$ & 0.804 & $5.56(4.42-7.64)$ \\
\hline $\mathrm{Pg} 1 / \operatorname{Pg} 2$ & $10.93(9.10-12.83)$ & 0.984 & $11.15(8.22-13.53)$ & 0.956 & $11.22(9.03-13.27)$ \\
\hline
\end{tabular}

ERD, erosive reflux disease; NERD, non-erosive reflux disease; IQR, interquartile range; G-17, Gastrin-17; Pg1, Pepsinogen-1; Pg2, Pepsinogen-2

patients with dyspepsia. Pathogenesis of GERD is linked to the functional state of gastric mucosa, so it was thought that measurement of biomarkers of gastric mucosa seemed to be a promising diagnostic tool.

In our study prior exclusion of the patients having conditions that may influence secretion of the biomarkers levels of G-17 and Pg2 were significantly lower and $\mathrm{Pg} 1 / \mathrm{Pg} 2$ higher in the ERD group compared to the control group. However, after exclusion of all conditions (antrum and corpus mucosa atrophy, Helicobacter pylori colonisation of antrum mucosa) that may influence levels of biomarkers, significant differences were lost. A study by Malfertheiner's group on biomarker levels among various forms of GERD showed similar results for a study population that had a much lower rate of gastric mucosa atrophy and Helicobacter pylori colonisation (Monkemuller et al., 2008).

No statistically significant difference among biomarker levels was observed between NERD and the control group before exclusion of all conditions that may influence biomarker levels, nor after exclusion of those conditions. However, in a study from Japan, NERD was linked with decreased level of Pg1/Pg2 (Fujiwara et al., 2005). Another study from Japan found that both ERD and NERD patients had increased level of Pg1/Pg2 (Minatsuki et al., 2013).

In our study almost all patients in the ERD group presented in the A or B esophagitis stage, which may have influenced the obtained results. However, a significant difference was also not observed in the levels of biomarkers in a matched case-control study (Monkemuller et al., 2008).

Although BE is considered as a form of GERD, the sampled group in our study contained no BE patients. A lower level of G-17 (Sipponen et al., 2005) and higher level of Pg1 (Abe et al., 2009) have been observed in BE patients.

On the one hand, levels of biomarkers are indirect indicators of the functional state of gastric mucosa, which is why they can be successfully used for non-invasive diagnostic of atrophic gastritis (Kuipers, 2003; Vaananen et al., 2003; Pasechnikov et al., 2005; Iijima et al., 2009; Narsollahzadeh et al., 2011). On the other hand, this likely is not be the case for GERD patients (Peitz et al., 2011). Our data support the idea that GERD is a complex disease and it has a very complex pathophysiology; probably, increased gastric acid secretion is not the most important pathophysiological mechanism in ERD and NERD.

The most important limitation of our study was that the control group was represented not by healthy individuals, but by patients with various complaints from the side of upper gastrointestinal system. It is known that the pattern of pepsinogen secretion varies among patients with functional dyspepsia (Yoshikawa et al., 2002).

In summary, Pg1, Pg2, and G-17 based tests cannot be used to distinguish ERD or NERD from other dyspeptic patients. Also, ERD and NERD patients cannot be distinguished using serological tests only.

Considering the gastric acid secretion profile differs in BE compared to other patients, future studies should focus on clarifying the role of pepsinogen-based tests in the screening and diagnosis of $\mathrm{BE}$.

\section{ACKNOWLEDGMENTS}

We acknowledge the members of the Latvian Helicobacter pylori and gastric cancer study group, in particular: Viesturs Boka, Viesturs Putnin̋̌s, Armands Sīviņ̌s, Guntis Ancāns, Ilze Kikuste, Dans Stirna, Ingrīda RumbaRozenfelde, Līga Pañina, Aija Kārkliņa, Agita Vavilova, Galina Chui, Aigars Vanags, and Anita Lapina.

\section{REFERENCES}

Abe, Y., Iijima, K., Koike, T., Asanuma, K., Imatani, A., Ohara, S., Shimosegawa, T. (2009). Barrett's esophagus is characterized by the absence of Helicobacter pylori infection and high levels of serum pepsinogen I concentration in Japan. J. Gastroenterol. Hepatol., 24 (1), 129-134.

Collen, M. J., Johnson, D. A. (1992). Correlation between basal acid output and daily ranitidine dose required for therapy in Barrett's esophagus. Digestive Dis. Sci., 37 (4), 570-576.

Dixon, M. F., Genta, R. M., Yardley, J. H., Correa, P. (1996). Classification and grading of gastritis. The updated Sydney System. International workshop on the histopathology of gastritis, Houston 1994. Amer. J. Surg. Pathol., 20 (10), 1161-1181.

Dockray, G. J. (2004). Clinical endocrinology and metabolism. Gastrin. Best Practice Res. Clin. Endocrin. Metab., 18 (4), 555-568.

Fujiwara, Y., Higuchi, K., Shiba, M., Yamamori, K., Watanabe, Y., Sasaki, E., Tominaga, K., Watanabe, T., Oshitani, N., Arakawa, T. (2005). Differ- 
ences in clinical characteristics between patients with endoscopy-negative reflux disease and erosive esophagitis in Japan. Amer. J. Gastroenterol., 100 (4), 754-758.

Gritti, I., Banfi, G., Roi, G. S. (2000). Pepsinogens: Physiology, pharmacology pathophysiology and exercise. Pharmacol. Res., 41 (3), 265-281.

Iijima, K., Abe, Y., Kikuchi, R., Koike, T., Ohara, S., Sipponen, P. (2009). Serum biomarker tests are useful in delineating between patients with gastric atrophy and normal, healthy stomach. World J. Gastroenterol., 15 (7), 853-859.

Katz, P., Gerson, L. B., Vela, M. F. (2013). Guidelines for the diagnosis and management of gastroesophageal reflux disease. Amer. J. Gastroenterol., 108 (3), 308-328

Kuipers, E. J. (2003). In through the out door: Serology for atrophic gastritis. Eur. J. Gastroenterol. Hepatol., 15 (8), 877-879.

Lundell, L. R., Dent, J., Bennett, J. R., Blum, A. L., Armstrong, D., Galmiche, J. P., Johnson, F., Hongo, M., Richter, J. E., Spechler, S. J., Tytgat, G. N., Wallin, L. (1999). Endoscopic assessment of eosophagitis: clinical and functional correlates and futher validation of the Los Angeles classification. Gut, 45 (2), 172-180.

Minatsuki, C., Yamamichi, N., Shimamoto, T., Kakimoto, H., Takahashi, Y., Fujishiro, M., Sakaguchi, Y., Nakayama, C., Konno-Shimizu, M., Matsuda, R., Mochizuki, S., Asada-Hirayama, I., Tsuji, Y., Kodashima, S., Ono, S., Niimi, K., Mitsushima, T., Koike, K. (2013). Background factors of reflux esophagitis and non-erosive reflux disease: A cross-sectional study of 10,837 subjects on Japan. PLOS ONE, 8 (7). DOI: 10.1371/journal.pone.0069891.

Monkemuller, K., Neumann, H., Nocon, M., Vieth, M., Labenz, J., Willich, S. N., Stolte, M., Hocker, M., Jaspersen, D., Lind, T., Malftheiner, P. (2008). Serum gastrin and pepsiongens do not correlate with the different grades of severity of gastro-oesophageal reflux disease: A matched case-control study. Alimentary Pharmacol. Ther., 28 (4), 491-496.
Mulholland, N. M., Reid, B. J., Levine, D. S., Rubin, C. E. (1989). Elevated gastric acid secretion in patients with Barrett's metaplastic epithelium. Digest. Dis. Sci., 34 (9), 1329-1334.

Narsollahzadeh, D., Aghcheli, K., Sotoudeh, M., Shakeri, R., Persson, E. C. Islami, F., Kamangar, F., Abnet, C. C., Boffetta, P., Engstrand, L., Dawsey, S. M., Malekzadeh, R., Ye, W. (2011). Accuracy and cut-off values of pepsinogens I, II and gastrin 17 for diagnosis of gastric fundic atrophy: Influence of gastritis. PLOS ONE, 6 (10). DOI: 10.1371/journal.pone.0026957.

Pasechnikov, V. D., Chukov, S. Z., Kotelevets, S. M., Mostovov, A. N., Mernova, V. P., Polyakova, M. B. (2005). Invasive and non-invasive diagnosis of Helicobacter pylori-associated atrophic gastritis: A comparative study. Scand. J. Gastroenterol., 40 (3), 297-301.

Peitz, U., Wex, T., Vieth, M., Stolte, M., Willich, S., Labenz, J., Jaspersen, D., Lind, T., Malfertheiner, P. (2011). Correlation of serum pepsinogens and gastrin-17 with atrophic gastritis in gastroesophageal reflux patients: A matched-pairs study. J. Gastroenterol. Hepatol., 26 (1), 82-89.

Sipponen, P., Vauhkonen, M., Helske, T., Kaariainen, I., Harkonen, M. (2005). Low circulating levels of gastrin-17 in patients with Barrett's esophagus. World J. Gastroenterol., 11 (38), 5988-5992.

Tack, J., Talley, N. J., Camilleri, M., Holtmann, G., Hu, P., Malagelada, J.-R., Stanghellini, V. (2006). Functional gastroduodenal disorders. Gastroenterology, 130 (5), 1466-1479.

Vaananen, H., Vauhkonen, M., Helske, T., Kaariainen, I., Rasmussen, M., Tunturi-Hihnala, H., Koskenpato, J., Sotka, M., Turunen, M., Sandstrom, R., Ristikankare, M., Jussila, A., Sipponen, P. (2003). Non-endoscopic diagnosis of atrophic gastritis with a blood test. Correlation between gastric histology and serum levels of gastrin-17 and pepsinogen I: A multicentre study. Eur. J. Gastroenterol. Hepatol., 15 (8), 885-891.

Yoshikawa, I., Murata, I., Kume, K., Kanagawa, K., Hirohata, Y., Nakamura, H., Otsuki, M. (2002). Serum pepsinogen can predict response to H2-receptor antagonist in patients with functional dyspepsia. Alimentary Pharmacol. Ther., 16 (10), 1805-1809.

\section{GASTROEZOFAGEĀLĀ ATVILNNA NEINVAZĪVA DIAGNOSTIKA, IZMANTOJOT GASTRĪNA UN PEPSĪNA TESTUS}

Gastrīns-17 (G-17), pepsinogēns-1 (Pg1) un pepsinogēns-2 (Pg2) atspogulo kunǵa gḷotādas funkcionālo stāvokli, un tos izmanto atrofiska gastrīta neinvazīvai diagnostikai un skrīningam. Pētījuma mērḳis bija izvērtêt, vai ir iespējams atšḳirt erozīva gastroezofageālā atviḷna (EGEA) un ne-EGEA (NEGEA) pacientus no pārējiem pacientiem ar dispepsiju, izmantojot specifiskus neinvazīvus marķierus. G-17, Pg1 un Pg2 koncentrācijas asinīs tika izmērītas 141 EGEA pacientiem (vecuma mediāna 48 gadi, vīrieši - 68), 122 NEGEA pacientiem (vecuma mediāna 45 gadi, vīrieši - 32) un 410 kontroles pacientiem (vecuma mediāna 50 gadi, vīrieši - 97). Biomarkieru koncentrācijas EGEA un NEGEA pacientiem tika salīdzinātas ar kontroles grupu. EGEA pacientiem G-17 (1,94 vs 2,92 pmol/L, $p=0,036)$ un Pg2 $(6,70$ vs $7,79 \mu \mathrm{g} / \mathrm{L}, p=0,046)$ koncentrācijas bija zemākas, salīdzinot ar kontroles pacientiem, savukārt, NEGEA grupas biomarkieru koncentrācijas būtiski neatškīinās. Pēc to pacientu izslēgšanas no analīzes, kuriem bija vismaz viens faktors, kas var ietekmēt biomarkieru koncentrāciju asinīs (kuṇga gḷotādas atrofija, Helicobacter pylori kolonizācija), nozīmīgas biomarkieru koncentrācijas atškirības netika novērotas. Testus G-17, $\operatorname{Pg} 1$ un $\operatorname{Pg} 2$ koncentrāciju noteikšanai nevar izmantot EGEA un NEGEA atklāšanai dispeptisko pacientu vidū. 